Bangladesh J. Bot. 48(4): 925-932, 2019 (December)

\title{
FOURIER TRANSFORM INFRARED (FT-IR) SPECTROSCOPIC INVESTIGATIONS OF FOUR AGAROPHYTES FROM NORTHERN ARABIAN SEA
}

\author{
Laila Shahnaz ${ }^{1}$, Hina Shehnaz ${ }^{2 *}$ and Amir Haider ${ }^{3}$ \\ Department of Botany, University of Karachi, Pakistan
}

Keywords: FT-IR Spectroscopy, Agarophytes, Agar

\begin{abstract}
The fresh specimens of Champia compressa Harvey, Gelidium usmanghanii Afaq-Husain and M. Shameel, Gracilaria foliifera (Forsskål) Børgesen and Hypnea musciformis (Wulfen) J. V. Lamouroux, were collected from the coastal areas of Karachi (Pakistan) and their yield of agar was observed. With preextraction technique the percentage of algal yield was found to range from 13 to $28 \%$. High quality gel strength was determined by modulus of elasticity i.e. $\left(550-612 \mathrm{~g} / \mathrm{cm}^{2}\right)$ and $1090 \mathrm{kPa}$ and extraction time was $2 \mathrm{hrs}$. The structure of agar and agar contents were investigated by FT-IR spectroscopy for the first time from Pakistan. The results revealed some interesting characters (non sulphated $\beta$-D galacto pyranose residues, 3,6 anhydro galactose vibration), which were not reported earlier.
\end{abstract}

\section{Introduction}

The coastline of Pakistan is about $885 \mathrm{~km}$ long and rich in algal vegetation found either in growing and in drift form or attached to the rocks, occurring also in the sandy and rocky bottom of the pools (Shameel and Tanaka 1992). Algae produced a number of biologically and chemically active compounds such as aldehydes, fatty acids, halogenated compounds, sterols and terpenes (Aliya and Shameel 2003, Shahnaz and Shameel 2008, 2009). According to Bhadury and Wright (2004) algal metabolites have antibacterial, antifungal, and antibiofouling properties. Additionally, natural products isolated from seaweeds have pharmaceutical and medicinal uses in various parts of the world (Smit 2004).

Seaweeds the imperative revenue generating resources of the marine environment, have a fundamental and important position in traditional drug of all ancient civilizations of the world, i.e. Greek, Roman, Chinese and Indian and are exploited as vermifuges, aesthetics and antibiotics in the treatment of cough, wounds, gout, goiter, hypertension, cancer, venereal and a variety of other diseases (Smit 2004, South and Whittick 1987, Sridharan and Dhamotharan 2012). They also provide alginate, agar and carrageenan some of their carbohydrates (polysaccharides) are being used in the preparation of toothpastes, soaps, shampoos, and as a thickening agent in ice creams and milk (NAAS 2003). Particularly agar is widely used in leather, cosmetics, paper, textile, dairy and pharmaceutical industries. Moreover, it is the major component of culture media for microbiology laboratory (NAAS 2003).

A number of research work have been reported on sulfated polysaccharides commonly known as agar and cell wall constituents of red algae (Akahane and Izumi 1976, Villanueva and Montaño 1999, Freile-Pelegrin and Murano 2005, Laurienzo 2010, Villanueva et al. 2009, 2010a, b). The agarose is the major component of agar, the repeating agarobiose units blinking between 3linked $\beta$-D-galactopyranosyl $(\mathrm{G})$ and 4-linked 3,6-anhydro- $\alpha$-L-galactopyranosyl (LA) units. The sulfate hemi esters and methyl esters in a variety of groupings and with a cyclic pyruvate ketal as 4,6-O-[(R)-1-carboxyethylidene] acetal are modified by substitution of hydroxyl groups in

*Author for correspondence: <hinashehnaz@gmail.com>. ${ }^{2}$ Department of Environmental Sciences, Sind Madressatul Islam University, Karachi, Pakistan. ${ }^{3}$ Arysta Life Sciences, Pakistan. 
disaccharides, which forms the sustainable structure in the cell wall of several species of red seaweeds, and it is released on boiling (Praiboon et al. 2006, Hotchkiss and Trius 2007, Van et al. 2008).

In the present study the structure of agar extracted from the four different species of agarophytes i.e., C. compressa, G. usmanghanii, G. foliifera and H. musciformis by Fourier Transform Infrared (FT-IR) Spectroscopy. Previously no work has been reported about the vibrational band studies of agar from this region.

\section{Materials and Methods}

The specimens of $C$. compressa, G. usmanghanii, G. foliifera and H. musciformis were collected from the sandy bottom rocky pools of mid-littoral rocks at Buleji in the month of March 2012, from epilithic in mid to sub-littoral zones at Manora, Buleji and Paradise Point during August and September 2012, from rocky pools of mid-littoral rocks at Manora during January to April 2011, and as drift material from Manora and Buleji in the month of December 2012, respectively. The fresh algal specimens were washed with fresh water to remove the epiphytes, epizoons and attached sand particles and then with distilled water. The algal material in bulk was dried under shade.

Fifteen $\mathrm{g}$ dried thalli of each species were first soaked in $200 \mathrm{ml} \mathrm{NaOH}$ solution of $0,1,2,3$, 4 and $5 \%$ concentrations, respectively at $80-85^{\circ} \mathrm{C}$ for $1,2,3$ and $4 \mathrm{hrs}$. Whole thalli of $C$. compressa, G. usmanghanii, G. foliifera and H. musciformis were used in the extraction for alkali pretreatment process (Freile-Pelegrin and Robledo 1997, Villanueva et al. 2010 a,b). The $\mathrm{NaOH}$ solution was discarded and the pretreated samples were hydrated by soaking in $350 \mathrm{ml}$ of distilled water at room temperature, the same procedure was followed $2-3$ times for washing. Next they were soaked in dilute acetic acid solution of $0.5 \%$ for $1.5 \mathrm{hr}$ at room temperature, acetic acid solution was then decanted and again each species was washed with fresh water. Agarophytes were extracted from $350 \mathrm{ml}$ of distilled water at boiling temperature for $1.5 \mathrm{hr}$. Each species of all agar were grinded in blender to homogenize and filtered with the help of cotton cloth. The freeze thawing method was followed for the extraction of agar from the blended mixture of $C$. compressa, G. usmanghanii, G. foliifera and H. musciformis.

The extracted agar was then washed and treated with alcohol (ethanol) to reduce the water content from the freshly extracted agar, finally oven dried at $60^{\circ} \mathrm{C}$ and collected in air tight bottles. The best quality agar was extracted from the solution of $5 \% \mathrm{NaOH}$ solution with time duration of 4 hrs pretreatment process, Secondly the intense studies were carried out for the gel quality and the extraction time of each agar extracted from C. compressa, G. usmanghanii, G. foliifera and $H$. musciformis. After pretreatment process of $(\mathrm{NaOH})$ the solution was neutralized by acetic acid and seaweeds were extracted with $350 \mathrm{ml}$ distilled water at boiling temperature for 2, 3 and $4 \mathrm{hrs}$. The whole procedure proceeded in the alkali treatment and agar extraction section. The agar weight was determined by the percentage calculation of agar dry weight divided by seaweed dry weight mentioned in the following equation, (Armisen 1995, Villanueva et al. 2010 a,b).

$$
\text { Agar yield }=\frac{\text { Agar dry weight }(\mathrm{g})}{\text { Seaweed dry weight }(\mathrm{g})} \times 100
$$

In distilled water $2 \% \mathrm{w} / \mathrm{w}$ agar solution was prepared by boiling with continuous stirring, approximately $15 \mathrm{~g}$ of the hot solution was added to the cylindrical container (30 $\mathrm{mm}$ in diameter), allowed it to settle for $24 \mathrm{hrs}$. at room temperature and the solution was covered with aluminum foil. The depth of the gel was maintained in between 18 and $22 \mathrm{~mm}$. 
The consistency and quality of the gel and its apparent young's Modulus were determined by the Stable Micro System model TAXT2, Surrey, England. The methodology for the study of stress strain curve was followed by Hilliou et al. 2006 and (Villanueva et al. 2009, 2010a, b). The CSL rheometer was used for the rheological measurement with $3 \mathrm{~mm}$ thick agar gel slab loaded on pre heated up to $50-55^{\circ} \mathrm{C}$ Peltier plate and temperature was elevated up to $96-98^{\circ} \mathrm{C}$ to change the texture in the almost liquid state.

The overload sample was discarded and to minimize the probability of evaporation the sample was covered with paraffin oil. The cooling to heating scan was measured the storage $\left(\mathrm{G}^{\prime}\right)$ and loss $\left(\mathrm{G}^{\prime \prime}\right)$ moduli were measured at $5.91 \mathrm{rad} \mathrm{s}^{-1}$ with $0.1 \%$ strain and the temperatures at which crossover of the moduli occurred $\left(G^{\prime}=G^{\prime \prime}\right.$ or $\left.\tan d=1\right)$, the gelling and melting temperatures were considered as the cooling and heating scans, respectively. Typical curves for these rheological tests are presented by Villanueva and Montaño 1999, Villanueva et al. 2009, 2010b.

The statistical analysis was carried out by SPSS Statistics version 17.0. The two-way ANOVA applied for agar yield, gel strength and texture and to measure the considerable differences among the properties of different agars of all four species extracted in different time intervals.

The IR spectra were monitored on Shimadzu prestige-21 200 VCE coupled to a PIV-PC and loaded with IR solution version 1.2 software (potassium bromide disks). The dried powder $1 \mathrm{mg}$ each was mixed in a mortar with $99 \mathrm{mg}$ of $\mathrm{KBr}$. A thin $\mathrm{KBr}$ disc was obtained by pressing the powder in French press and FT-IR spectra were recorded (Villanueva and Montaño 1999, Rajasulochana et al. 2008, Mulbry et al. 2012).

\section{Results and Discussion}

The preliminary studies reveal that the agar extraction from 5\% sodium hydroxide solution has the best quality results from all the four species studied which have been under investigation for these extraction studies (Yaphe and Arsenault 1965, Rajasulochana et al. 2008). The effect of alkali concentration $(\mathrm{Y})$, agar yield (Z), gel strength, agar's melting point, apparent Young's Modulus and melting temperature of agar is presented in Table 1.

The treatment and extraction from different solutions of sodium hydroxide during pretreatment procedures significantly influenced the yield and quality of agar extracted from the species of different seaweeds. The statistical parameters of F-static and p-value reveal that the values are comparatively high, the values interaction endorsed that all the parameters are significant with high F-values (Table 1). The low agar yield was observed in $0 \% \mathrm{NaOH}$ solution from C. compressa (11\%), G. usmanghanii (14\%), G. foliifera (15\%) and H. musciformis (13\%). The best gels extracted from C. compressa, G. usmanghanii, G. foliifera and H. musciformis were $21,23,19$, and $21 \%$, respectively when treated with $4 \% \mathrm{NaOH}$ solution and $36,33,35$ and $34 \%$ respectively when treated with $5 \% \mathrm{NaOH}$ solution. On the other hand the weak gels extracted (11, 14,15 , and $13 \%$, respectively from the above species) from the solution of zero per cent alkali with very fragile polymeric capacity even was difficult to recover after washing with alcohol (Villanueva and Montaño 1999, Trivedi and Kumar 2014).

The Young's modulus results and agar gel strength have same responses in all the four species of algae, lowest agar gel strength was observed at $0 \% \mathrm{NaOH}$ pretreatment conditions whereas the agar gel quality was increased as the concentration of $\mathrm{NaOH}$ increased during pretreatment conditions. From the $5 \% \mathrm{NaOH}$, the best agar gel extracted has the highest value of $589 \mathrm{~g} / \mathrm{cm}^{2}$ in C. compressa, $612 \mathrm{~g} / \mathrm{cm}^{2}$ in G. usmanghanii, $550 \mathrm{~g} / \mathrm{cm}^{2}$ in G. foliiferaand $582 \mathrm{~g} / \mathrm{cm}^{2} \mathrm{H}$. musciformis, so the $5 \% \mathrm{NaOH}$ was the best concentration of the alkali solution for excellent agar extraction technique. 
The representative local agar when compared with alkali treated agars extracted from the $C$. compressa, G. usmanghanii, G. foliifera and H. musciformis possess almost similar FT-IR bands and they are in close resemblance with that of standard Difco Agar from Merck. The FT-IR spectroscopic studies mentioned in Table 2 while the collected seaweeds were preserved in the form of herbaria (Villanueva et al. $2010 \mathrm{a}, \mathrm{b}$ ).

Table 1. The SPSS statistics on the different properties of agar extracted from Champia compressa, Gelidium usmanghanii, Gracilaria foliifera and Hypnea musciformis.

\begin{tabular}{llllllc}
\hline Agar property & \multicolumn{2}{l}{$\mathrm{NaOH}$ concentration (X) } & \multicolumn{2}{l}{ Pretreatment duration (Y) } & \multicolumn{2}{c}{$\mathrm{Y} \times \mathrm{Z}$} \\
\hline Champia compressa & $\mathrm{F}$ & $\mathrm{p}$ & $\mathrm{F}$ & $\mathrm{p}$ & $\mathrm{F}$ & $\mathrm{p}$ \\
Agar yield & 110.54 & 0.0001 & 7.58 & 0.0001 & 4.12 & 0.0039 \\
Gel strength & 70.12 & 0.0012 & 30.69 & 0.0001 & 11.25 & 0.0002 \\
Apparent Young's modulus & 61 & 0.0001 & 17.89 & 0.0019 & 2.99 & 0.0018 \\
Gelling temperature & 141.41 & 0.0001 & 9.01 & 0.0188 & 8.21 & 0.0001 \\
Melting temperature & 30.12 & 0.0001 & 8.88 & 0.0031 & 3.89 & 0.0003 \\
Gelidium usmanghanii & & & & & & \\
Agar yield & 121.60 & 0.0017 & 8.78 & 0.0042 & 3.05 & 0.0031 \\
Gel strength & 69.14 & 0.0001 & 32 & 0.0001 & 10.02 & 0.0018 \\
Apparent Young's modulus & 58.54 & 0.0011 & 16.99 & 0.0002 & 3.77 & 0.0014 \\
Gelling temperature & 137.41 & 0.0001 & 9 & 0.0002 & 8.5 & 0.0001 \\
Melting temperature & 32.78 & 0.0001 & 8.88 & 0.0014 & 3.02 & 0.0065 \\
Gracilaria foliifera & & & & & & \\
Agar yield & 119.25 & 0.0023 & 8.19 & 0.0045 & 4.12 & 0.0029 \\
Gel strength & 72.47 & 0.0011 & 28.77 & 0.0001 & 11.25 & 0.0001 \\
Apparent Young's modulus & 59.5 & 0.0001 & 18 & 0.0001 & 2.99 & 0.0015 \\
Gelling temperature & 133.2 & 0.0001 & 9.3 & 0.0178 & 8.21 & 0.0003 \\
Melting temperature & 29.2 & 0.0001 & 8.45 & 0.0001 & 3.89 & 0.0074 \\
Hypnea musciformis & & & & & & \\
Agar yield & 122 & 0.0014 & 6.98 & 0.0003 & 3.18 & 0.0031 \\
Gel strength & 68.47 & 0.0015 & 33.12 & 0.0014 & 1.89 & 0.0001 \\
Apparent Young's modulus & 57 & 0.0011 & 20.14 & 0.0001 & 3.58 & 0.0013 \\
Gelling temperature & 139 & 0.0014 & 8.66 & 0.0002 & 7.45 & 0.0069 \\
Melting temperature & 28.77 & 0.0001 & 7.78 & 0.0036 & 4.18 & 0.0010 \\
\hline
\end{tabular}

FT-IR has generally used in biological materials as discussed and represented in various research articles, the spectra of the samples of C. compressa, G. usmanghanii, G. foliifera and $H$. musciformis are presented in (Tables $1-2$ ) and their probable assignments on the vibrational frequencies are arranged as follows:

The FT-IR spectra of the samples exhibited at $3450 \mathrm{~cm}^{-1}$ and confirm the observation (South and Whittick 1987). 
Table 2. FT-IR band assignment of standard agar and agars obtained from Champia compressa, Gelidium usmanghanii, Gracilaria foliifera and Hypnea musciformis (frequency/cm).

\begin{tabular}{|c|c|c|c|c|c|}
\hline $\begin{array}{l}\text { Band } \\
\text { assignments }\end{array}$ & $\begin{array}{c}\text { Standard } \\
\text { agar }\end{array}$ & $\begin{array}{c}\text { Champia } \\
\text { compressa }\end{array}$ & $\begin{array}{c}\text { Gelidium } \\
\text { usmanghanii }\end{array}$ & $\begin{array}{c}\text { Gracilaria } \\
\text { foliifera }\end{array}$ & $\begin{array}{c}\text { Hypnea } \\
\text { musciformis }\end{array}$ \\
\hline $\begin{array}{l}\text { C-S linked vibration/S-O } \\
\text { stretch/C-S deformation }\end{array}$ & $690 \mathrm{~s}$ & 688 & 672 & 687 & 669 \\
\hline $\begin{array}{l}\text { C-S linked vibration/S-O } \\
\text { stretch/C-S deformation }\end{array}$ & $780 \mathrm{~s}$ & 762 & 780 & 785 & 769 \\
\hline $\begin{array}{l}\text { Ester sulphate in C-2 link } \\
\text { vibration/C-C/C-O/C-O-S } \\
\text { stretch }\end{array}$ & & 832 & 850 & 845 & 849 \\
\hline $\begin{array}{l}\text { Non sulphated } \beta \text {-D galacto } \\
\text { pyranose residues/C-C/C-O } \\
\text { stretch }\end{array}$ & $885 \mathrm{~s}$ & 895 & 880 & 892 & 878 \\
\hline $\begin{array}{l}\text { 3,6 anhydro galactose } \\
\text { vibration/C-C/C-O/C-O-S } \\
\text { stretch }\end{array}$ & $935 \mathrm{~s}$ & 936 & 930 & 925 & 931 \\
\hline $\begin{array}{l}\text { Ester sulphate link } \\
\text { vibration/C-C/C-O/C-O-S } \\
\text { stretch }\end{array}$ & 1045 vs & 1048 & 1051 & 1039 & 1050 \\
\hline $\begin{array}{l}\text { Ester sulphate link } \\
\text { vibration/C-C/C-O/C-O-S } \\
\text { stretch }\end{array}$ & $1165 \mathrm{~s}$ & 1161 & 1162 & 1170 & 1175 \\
\hline $\begin{array}{l}\text { Methyl group vibration } / \mathrm{S}=\mathrm{O} \\
\text { symmetric stretch }\end{array}$ & 1375 & 1381 & 1383 & 1385 & 1380 \\
\hline $\begin{array}{l}\text { Methyl group vibration } / \mathrm{S}=\mathrm{O} \\
\text { asymmetric stretch }\end{array}$ & 1438 & 1435 & 1442 & 1445 & 1439 \\
\hline $\begin{array}{l}\mathrm{C}=\mathrm{O} \text { symmetric stretch } / \mathrm{N}-\mathrm{H} \\
\text { deformation }\end{array}$ & & 2880 & 2865 & 2868 & 2885 \\
\hline $\begin{array}{l}\mathrm{C}=\mathrm{O} \text { symmetric stretch } / \mathrm{N}-\mathrm{H} \\
\text { deformation }\end{array}$ & 1650 & & & & \\
\hline $\mathrm{N}-\mathrm{H}$ deformation & 1555 & 1551 & 1559 & 1549 & 1558 \\
\hline $\mathrm{C}=\mathrm{O}$ stretch & 1737 & & & & \\
\hline $\begin{array}{l}\text { Methyl group vibration/C-H } \\
\text { symmetric stretch }\end{array}$ & & 2875 & 2874 & 2868 & 2871 \\
\hline $\begin{array}{l}\text { Methyl group vibration/C-H } \\
\text { asymmetric stretch }\end{array}$ & 2932,3420 & 2940,3431 & 2945,3433 & 2939,3425 & 2928,3445 \\
\hline $\mathrm{OH} / \mathrm{N}-\mathrm{H}$ stretch & 3475 & 3481 & 3478 & 3470 & 3469 \\
\hline
\end{tabular}

In all the four spectra the $\mathrm{N}-\mathrm{H}$ stretching appeared as a combination band with stretching band of $-\mathrm{OH}$ G. usmanghanii showed absorption at $3545 \mathrm{~cm}^{-1}$, in G. foliifera the N-H stretching appeared at $3457 \mathrm{~cm}^{-1}$, C. compressa and H. musciformis showed their absorption band at 3461 $\mathrm{cm}^{-1}$.

Methyl group has two types of stretching vibrations. In alkane $\mathrm{C}-\mathrm{H}$ asymmetric stretching band occurs at 2939, 2940, 2928 and $2945 \mathrm{~cm}^{-1}$ and symmetric stretching vibrations observed at $2885 \mathrm{~cm}^{-1}$. The FTIR spectra of G. usmanghanii has weak bands were exhibited for methyl group for asymmetric stretching at $2878 \mathrm{~cm}^{-1}$, for G. foliifera the asymmetric stretching was observed at $2889 \mathrm{~cm}^{-1}$ with very weak bands appeared due to methyl substituent, the asymmetric vibration of 
C. compressa was appeared at $2884 \mathrm{~cm}^{-1}$ and the asymmetric vibration frequency of $H$. musciformis was appeared at $2880 \mathrm{~cm}^{-1}$ (Freile-Pelegrin and Murano 2005).

Ester-sulphate link vibration of G. usmanghanii was manifested at $1080 \mathrm{~cm}^{-1}$, for G. foliifera vibration observed at $1180 \mathrm{~cm}^{-1}$ and for $C$. compressa and H. musciformis they appeared at 1202 and $1156 \mathrm{~cm}^{-1}$, respectively (Akahane and Izumi 1976). The intensity of the absorptions vary was found to from medium strong to weak or even very weak and it depends up on the species. The bands at 1075 to $1125 \mathrm{~cm}^{-1}$ are due to symmetric stretching of S-O/C-O and asymmetric vibrations occurred at $1245-1370 \mathrm{~cm}^{-1}$. The sulphate ester of C-6 linkage was observed at $880 \mathrm{~cm}^{-1}$ in $G$. usmanghanii, in G. foliifera it appeared at $885 \mathrm{~cm}^{-1}$ in C. compressa this peak appeared at 895 $\mathrm{cm}^{-1}$ and in $H$. musciformis this absorption was appeared at $865 \mathrm{~cm}^{-1}$. The $\beta$-D-galactose pyranose residues are well known agar peak according to the literature survey (Troung et al. 1988).The additional peaks 830,846 and $821 \mathrm{~cm}^{-1}$ were noticed in the spectrum of rest of the samples of $G$. foliifera, $C$. compressa and $H$. musciformis which is the representative peak of sulphate ester C-2 link absorptions. The linkage of C-S absorption of polysaccharides has been reported in literature in the region of $670-770 \mathrm{~cm}^{-1}$. The spectra of present study showed the strong bands to weak bands over the range of $670-770 \mathrm{~cm}^{-1}$ which may be attributed to the deformation of the sulphate linkage.

The strong to weak bands occurring at $936-925$ and $1039-1051 \mathrm{~cm}^{-1}$ in spectra of the present study are attributed to $\mathrm{C}-\mathrm{O}$ ether bond of 3, 6 anhydro galactose vibration as observed in the previous work these two peaks are archetypal vibrations of phycocolloides.

In the present work, the strong absorption bands at $1650 \mathrm{~cm}^{-1}$ was assigned for carbonyl vibrations of carboxylic group (-COO) due to asymmetric stretching of $\mathrm{C}=\mathrm{O}$ band. The medium to weak intensity band of $\mathrm{C}=\mathrm{O}$ of symmetrical stretching was observed at $1545 \mathrm{~cm}^{-1}$ which was also reported previously (Mulbry et al. 2012).

The presence of protein in polysaccharides shows carbonyl absorption as amide group. Primary and secondary amides display a band in the region $1640 \mathrm{~cm}^{-1}$ and very weak band of 1540 $\mathrm{cm}^{-1}$ has been reported which also been discussed by (Mulbry et al. 2012). A sharp peak appeared in the region of $3469-3481 \mathrm{~cm}^{-1}$ due to $\mathrm{N}-\mathrm{H}$ stretching vibration and all these vibrations have been presented first time in this study.

The C-C vibrations are weak in the region of $1200-800 \mathrm{~cm}^{-1}$ all the bands in this region are in the overlapping of $\mathrm{C}-\mathrm{C}$ and $\mathrm{C}-\mathrm{H}$ stretching that's why it is difficult to differentiate between these weak and small bands in this region.

This linkage of C-S polysaccharides band was observed in between the range of $670-770$ $\mathrm{cm}^{-1}$ and the strong to weak bands has been recorded for the deformation of sulphate in all the four species of the C. compressa, G. usmanghanii, G. foliifera and H. musciformis.

The results revealed that the alkali treatment was the ideal method for the extraction of better quality of agar from the different species of red algae i.e. C. compressa, G. usmanghanii, G. foliifera and $\mathrm{H}$. musciformis, while from non-alkali treatment method the poor-quality agar has been extracted. Gel strength and apparent Young's modulus results showed that there was a marked difference between all the treatments and the shorter extraction time was ideal for the better gel production. The intensity of bands varies with algal resources. The spectra of all the four samples exhibited consistent observations as similar to those shown by standard agar. It is interesting to note that a broad band is exhibited in the studied samples at $1245 \mathrm{~cm}^{-1}$, which is specific peak of sulphate esters. The peak is corresponding to as hump in standard agar, point to that the phycocolloids from these species contain a greater amount of sulphate esters as compared to the standard agar. The quality of agar is the indication of measure of substitution patterns, which differ in general with basic bands. In the present study, agar obtained from C. compressa, 
G. usmanghanii, G. foliifera and H. musciformis are more sulphated than standard agar, and consequently provide soft gelling agars which could be suitable for food industries.

\section{References}

Akahane T and Izumi S 1976. Sulfate groups of the mucilage of red sea weeds (Rhodopheceae). Agric. Biol. Chem. 40: 285-289.

Aliya R and Shameel M 2003. Marine natural products of Caulerpa (Siphonocladophyceae). Pak. J. Bot. 35: 659-699.

Armisen R 1995. World-wide use and importance of Gracilaria. J. Appl. Phycol.7: 231-243.

Bhadury P and Wright PC 2004. Exploitation of marine algae: biogenic compounds for potential antifouling applications. Planta 219: 561-578.

Freile-Pelegrm Y and Murano E 2005. Agars from three species of Gracilaria (Rhodophyta) from Yucatan Peninsula. Bioresour. Technol. 96: 295-302.

Freile-Pelegrín Y Robledo D 1997. Influence of alkali treatment on agar from Gracilaria cornea from Yucatán, México. J. Appl. Phycol. 9:533-539.

Hilliou L, Larotonda FDS, Abreu P, Ramos AM, Sereno AM and Gonçalves MP 2006. Effect of extraction arameters on thechemical structure and gel properties of $\kappa / \mathrm{t}$-hybrid carrageenans obtained from astocarpus stellatus. Biomol. Eng. 23: 201-208.

Hotchkiss S and Trius A 2007. Seaweed: The most nutritious form of vegetation on the planet? Food Ingredients Health and Nutr. 1:22-33.

Laurienzo P 2010. Marine polysaccharides in pharmaceutical applications: An overview Mar Drugs. 8: 24352465.

Mulbry W, Reeves J, Liu Y, Ruan Z and Liao W 2012. Near- and mid-infrared spectroscopic determination of algal composition. J. Appl. Phycol. 24: 1261-1267.

NAAS 2003. Seaweeds cultivation and utilization. Policy paper 22. Nat. Acad. Agric. Sci., India. 1-6 pp. ttp/naasindia.org/Policy\%20Papers/pp22.pdf.

Praiboon J, Chirapart A, Akakabe Y, Bhumibhamon O and Kajiwara T 2006. Physical and chemical characterization of agar polysaccharides extracted from the Thai and Japanese species of Gracilaria. Sci. Asia. 32: 11-17.

Rajasulochana N, Baluswami M, Parthasarathy MDV and Krishnamurthy V 2008. FT-IR spectroscopic investigation of the agars from Centroceras clavulatum and Spyridia hypnoides. Int. J. Phycol. Phycochem. 4: 125-130.

Shahnaz L and Shameel M 2008. Phycochemistry and bioactivity of twocoenocytic green seaweeds from Karachi coast. Int. J. Phycol. Phycochem. 4:13-18.

Shahnaz L and Shameel M 2009. Phycochemistry and bioactivity of some seaweeds from Karachi coast. Int. J. Algae 11: 377-393.

Shameel M and Tanaka J 1992. A preliminary check-list of marine algae fromthe coast and inshore waters of Pakistan. In: Cryptogamic Flora of Pakistan. Vol. I. (Eds.) Nakaike T and Malik S. Nat. Sci. Mus., Tokoyo, pp. 1-64.

Smit AJ 2004. Medicinal and pharmaceutical uses of seaweed natural products: A review. J. Appl. Phycol. 16: $245-262$.

South GR and Whittick A 1987. Introduction to phycology. Blackwell scientific publication, Oxford press, London. 21-25 pp.

Sridharan MC and Dhamotharan R 2012. Antibacterial activity of marine brown alga Turbinaria conoides. J. Chem. Pharm. Res. 4: 2292-2294.

Trivedi TJ and Kumar A 2014. Efficient extraction of agarose from red algae using ionic liquids. Green and Sustainable Chem. 4: 190-201.

Troung HH, Lesecq P, Karamanos I, Quang YVo and Christiaen D 1988. Chemical characteristics of agar from an agarophyte grown in the lagoon of Binh Tri Thien (Vietnam). Bot. Mar. 31: 289-293. 
Van TTT, Ly BM, Buu NQ and Kinh CD 2008. Structural characterization of agar extractedfrom six red seaweed species growing in the coast of Vietnam. Ajstd. 25: 395-403.

Villanueva RD and Montaño N 1999. Highly methylated agar from Gracilaria edulis (Gracilariales, Rhodophyta). J. Appl. Phycol. 11: 225-227.

Villanueva RD, Hilliou L and Sousa-Pinto I 2009. Postharvest culture in the dark: an eco-friendly alternative to alkali treatment for enhancing the gel quality of $\kappa / \mathrm{l}$-hybrid carrageenan from Chondrus crispus (Gigartinales, Rhodophyta). Bioresour. Technol. 100: 2633-2638.

Villanueva RD, Romero JB, Ragasa ALR and Montaño MNE 2010a. Agar from the red seaweed, Laurencia flexilis (Ceramiales, Rhodophyta) from northern Philippines. Phycol. Res. 58: 151-156.

Villanueva RD, Sousa AMM, Gonçalves MP, Nilsson M and Hilliou L 2010b. Production and properties of agar from the invasive marine alga, Gracilaria vermiculophylla (Gracilariales, Rhodophyta). J. Appl.Phycol. 22: 211-220.

Yaphe W and Arsenault GP 1965. Improved resorcinol reagent for the determination of fructose, and of 3, 6anhydrogalactose in polysaccharides. Anal. Biochem. 13: 143-148.

(Manuscript received on 27 June 2018; revised on 8 November, 2018) 